\title{
The Development of Audio Visual Learning Media Based on Genius Learning in Exposition Text Learning by Grade X SMK Tritech Informatika Medan
}

\author{
Ardina $^{1}$, Abdurahman Adisaputera ${ }^{2}$, Sumarsih ${ }^{3}$ \\ ${ }^{1,2,3}$ Universitas Negeri Medan, Indonesia \\ ardina429@gmail.com
}

\section{Abstract}

This study aims to determine: (1) Describe the audio visual learning media based on genius learning which is effective for class $X$ students of SMK Tritech Informatika Medan, (2) Describe the results of the development carried out on genius learning-based audio visual media for class X SMK Tritech Informatika students. Medan, (3) Describe the reasons for using audio-visual learning media based on genius learning in developing exposition text learning media. This research is a development research using the Borg \& Gall model which aims to develop an audio-visual learning media based on genius learning that will be used as an exposition text learning medium. This learning media will be tested from material experts, design experts, media experts, Indonesian language teachers, and students of SMK Tritech Informatika Medan, consisting of 3 students in individual trials, 9 students in small group trials, and 25 students in field trials. The instrument used in this study was a questionnaire. (1) The results of validation by material experts with an average of $79 \%$ with good criteria, (2) validation results by media experts with an average of $80 \%$ with good criteria, (3) validation by instructional media design experts with an average of $82 \%$ with very good criteria, (4) the response of Indonesian language teachers with an average of $86 \%$ with very good criteria, (5) the acquisition of individual trial results with an average of $78.5 \%$ with good criteria, (6) The acquisition of trial results small group with an average of $79 \%$ with good criteria, (7)Acquisition of field trial results with an average of $83.54 \%$ with very good criteria, (8) Student learning outcomes before using audio-visual learning media based on genius learning were 66.2 and after using audio-visual learning media based on genius learning with an average score of 78 in the good category. The difference obtained is 11.8. This proves that the genius learning-based audio-visual learning media developed can improve student learning outcomes, thus, this genius-based audiovisual learning media is effectively used in learning exposition text.
Keywords

development; learning media; exposition text; learning genius

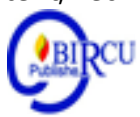

\section{Introduction}

Given the importance of a medium in learning, various media emerged and each media has its own character. Therefore, the teacher must try to choose carefully so that it can be used appropriately. Various kinds of media can also be used as teaching aids, namely (1) human-based media, (2) print-based media, (3) visual-based media, (4) audio-based media, and (5) computer-based media. (Leshin, Pollock \& Reigeluth in Arsyad, 2015: 38). 
Based on the results of interviews with Indonesian language subject teachers at SMK Tritech Medan, that the use of exposition text learning media in these schools still uses media in the form of markers and blackboards. According to them, the media is considered ineffective and effective for learning to write exposition text for $\mathrm{X}$ grade high school students, so they tend to choose to take students directly outside the classroom to help find ideas and inspiration. But even though seeing the natural surroundings is considered more effective for finding ideas in writing, in fact student conditioning becomes more difficult because the scope for monitoring and controlling students becomes wider. Another obstacle is the students' work in writing low exposition text. Through the school, it was found that the students' ability in the exposition text material was still categorized as lacking. This is known from the results of the students' acquisition, namely the average value of students' ability in learning exposition text 64 with completeness only $62 \%$ of students who were able to write exposition text properly and correctly. It can be proven that the difficulty of students expressing their opinions or ideas does not understand the rules and linguistic structures of the exposition text. The reciprocal communication relationship is in accordance with the purpose of communication, everything related to the communication process must be considered.

This is reinforced by Bahri (2016) in his journal entitled "Increasing the Ability to Write Expositional Text Using the Cush Word Method. The difficulties faced by students are an obstacle to learning to write expositional text in schools, so that students are less interested and enthusiastic in learning to write exposition text. Students also tend to be bored, bored, and uninspired. This happens because in teacher learning still uses conventional media in the form of pictures or portraits. Media that should be able to increase enthusiasm and motivate student learning becomes something that is boring for students. This is evidence that the learning media used are still not suitable and unable to improve students' understanding in learning to write exposition textStudents admit to having difficulty expressing ideas or ideas when given a writing assignment. As a result, some students' writing is the result of copying other people's writings. Based on the writer's observations when making observations, teachers usually convey learning to write with the lecture method which tends to be monotonous. This makes students experience less meaningful learning. As a result, students' interest and writing results are classified as low.

The use of audio-visual learning media can be a good alternative to excite students in learning to write exposition paragraphs. This is because the audio visual media can be used by the teacher to add a new dimension that can present moving images to students, in addition to the accompanying sound, so that students feel they are in the same place as the program that is broadcasted by audio visual media.

The use of genius learning strategies in audio-visual media is a practical approach in an effort to improve the results of the learning process by using knowledge from various disciplines, such as knowledge of how memory works, brain work, personality, emotions, learning styles, multiple intelligence and other knowledge. which can help the effectiveness of the teaching and learning process, especially in writing an exposition text. This statement is reinforced by Juliani and Rahmat (2013) in their journals that;Genius Learning is a term used to describe a series of practical approaches in improving the results of the learning process which has eight stages of learning.

Based on previous research, learning to write in students using media can help student achievement and present a pleasant atmosphere. Choosing the right media is expected to change students' paradigms about boring writing activities into something fun, especially in writing exposition text. Starting from an assumption The writer tries to use audio-visual 
media based on genius learning strategy. It is hoped that students will be able to make good and correct paragraph exposition.

Audio visual media based on genius learning namely the type of media which in addition to containing sound elements also contains image elements which begins with exploring and understanding the needs of students through the correct learning style through media developed to suit the full potential of students. In audio-visual media based on genius learning, it will lead students to actively undergo learning. The developed media has examples and builds communication with students. The teacher can find out whether he is learning according to the plan prepared based on the media.

\section{Review of Literatures}

\subsection{Learning Media}

According to Prasasti (2019) media is a word derived from the Latin medius, which literally means middle, intermediary, or introduction. Learning media, according to Kemp \& Dayton in Arsyad (2015: 23), can fulfill three main functions if the media is used for individuals, groups, or large groups of listeners, namely: (1) motivating interest or action, (2) presenting information, and (3) giving instructions. To fulfill the motivation function, learning media can be realized with drama or entertainment techniques. The expected result is to generate interest and stimulate students to take action. Rossi and Breidle in Sanjaya (2006: 163) argue that "learning media are all tools and materials that can be used to achieve educational goals such as radio, television, books, newspapers, magazines and so on." Devices such as radio and television, if used and programmed for education, are learning media.

Sitorus (2020) states that the use of media and technology and media by the teacher is additional support during teacher-centered teaching,Broadly speaking, the media are people, materials, or events that build conditions so that students are able to gain knowledge, skills, or attitudes. More specifically, the notion of media in the teaching and learning process tends to be defined as graphic, photographic, or electronic tools to capture, process, and reconstruct visual or verbal information. Thus it can be concluded that, media is an inseparable part of the teaching and learning process in order to achieve educational goals in general and learning objectives in schools in particular.

\subsection{Audio Visual Media}

Audiovisual media is a medium that is able to stimulate the sense of sight and sense of hearing together, because this media has sound and picture elements (Djamarah, 2006: 124). Audiovisual media are media that can be heard and seen (Dirdjosoemarto, 2000: 19).

Audio visual learning media is a medium that delivers material using mechanical and electronic machines to present audio-visual messages. For example film projectors, television, video and so on. One type of audio-visual learning media is video (Seel and Richey in Arsyad, 2011: 30). So, teaching through audio-visual is the production and use of material whose absorption through sight and hearing is not entirely dependent on understanding words or similar symbols.

Audio-visual media, which is a type of media that in addition to containing sound elements also contains visible image elements, for example video recordings, various sizes of films, sound slides and so on. The ability of this media is considered to be better and more attractive, because it contains two elements of the first and second types of media. 
The types of audio visual media are as follows:

\section{a. Pure Audio Visual}

Pure audio visual or often called audio-visual motion media, namely media that can display sound elements and moving images, sound elements and image elements come from a source.

\section{Sound Films}

There are various types of sound films, some are used for entertainment such as commercial films shown in cinemas. However, the sound films referred to in this discussion are films as learning tools. Film is a medium that has a very large ability in helping the teaching and learning process. A good film is a film that can meet the needs of students in relation to what is learned.

\section{Video}

Video as an audio-visual media that displays motion, is increasingly popular in our society. The messages conveyed can be factual or fictional, can be informative, educational or instructional, most of the tasks of film can be replaced by video. But that does not mean video can replace the position of film .

\section{Televise}

Apart from films and videos, television is a medium that delivers audio-visual learning messages.

\section{b. Impure Audio Visual}

Impure audio visual, namely media whose sound and image elements come from different sources. This impure audio visual is often referred to as silent audio visual plus sound, namely media that displays sound and still images such as:

\section{Sound slide (Movie sound frame)}

Slide or filmstrip added with sound is not a complete audio-visual tool, because sound and appearance are separate, therefore slides or filmstrips include audio-visual media only or silent visual media plus sound. Combined slide (frame film) with audio tape is the easiest type of multimedia system to produce. The combined slide and tape learning media can be used at various locations and for various learning purposes involving pictures to inform or encourage emotional responses. Sound slides are an innovation in learning that can be used as a learning medium and can effectively help students understand abstract concepts to be more concrete. By using sound slides as a medium of learning in the teaching and learning process can lead to more and more student senses involved (visual, audio). With the increasing number of senses involved, it is easier for students to understand a concept. Sound slides can be created using a combination of various computer applications such as: Power Point, Camtasia and Windows Movie Maker.

The author will develop an audio visual learning media using the Adobe After Effects application on the exposition text material.

\subsection{Understanding the Genius Learning Strategy}

In language, genius learning comes from two words, Genius which means smart and learning which means learning. So Genius Learning is learning done smartly. Whereas in a real sense, the Genius Learning strategy is a term used to describe a series of practical approaches in an effort to improve the results of the learning process. This approach is 
achieved by using knowledge that comes from various disciplines, such as knowledge of personality, emotions, intelligence, learning styles and others.

From the general understanding above, it can be concluded that the Genius Learning strategy is a series of practical approaches in an effort to improve the results of the learning process by using knowledge from various disciplines, such as knowledge of how memory works, brain work, personality, emotions, learning styles, multiple intelligence and other knowledge that can help the effectiveness of the teaching and learning process.

In applying the Genius Learning strategy, we depart with a belief and hope that if every child is educated can be properly motivated and taught in the right way, a way that respects the uniqueness of all of them can achieve maximum learning outcomes. The approach used in Genius Learning helps students to understand the strengths and strengths of a brand that suits their respective learning styles. Students will understand the correct learning process. They will learn the correct way of learning, according to their individuality and uniqueness.

Having a teacher and students in the classroom does not mean that the educational process can take place automatically. If there is a teaching process, it does not mean that it is followed by a learning process. Both of these processes are strived to be achieved simultaneously. However, it should be understood that they are two different activities. For this reason, Genius Learning is designed, namely to bridge the gap that separates the teaching process and the learning process.

Sardiman A. M in his book, Teaching and Learning Interaction and Motivation, also explains that learning is always a change in behavior or appearance, with a series of activities such as reading, observing, listening, imitating and so on. It is also better if the subject is learning. experience or do it.

\subsection{Exposition Text}

The Ministry of Education and Culture (2013: 12) states, "Text is a unit of language that contains complete meaning, thoughts and ideas." Text is not always in the form of written language, as commonly understood. Text can be in the form of both written text and spoken text (a combination of spoken and written text. as well as pictures, animation, film). According to Kosasih (2012: 17) "exposition text is a text that describes a number of knowledge or information. the text describes or describes a thing or object with clarity. " Mahsun (2013) states, "Text is an expression of the human mind in which there is a situation and context.

Furthermore, the Ministry of Education and Culture (2013: 77) states, "Text is a language (both spoken and written) that is contained in a situation context and cultural context. The context of the situation is the direct environment that is in the text. While the cultural context is a system of values and norms that represent a belief in a culture.

From the above opinion, it can be concluded that the text is an expression of thoughts both oral and written in which there is a cultural context and situation. As has been stated, the existence of the text is always surrounded by its environment, both physical and non-physical, which directly supports the existence of the text. In other words, the text is always in its context, the context of the situation and the cultural context that always accompanies it. 


\section{Research Method}

This research was conducted at SMK Tritech Informatika Medan. The experimental treatment was carried out for 2 meetings with a time allocation of $2 \times 40$ minutes for each meeting. The implementation stage of this research was carried out in the 2019/2020 learning year. The learning process is carried out in the classroom and computer lab. The type of research used is Research and Development using the Borg \& Gall development model (in Tegeh, 2014: 7). The product development of learning media for exposition text based on Genius Learning requires material experts, media experts, learning design experts, and class X students of SMK Tritech Informatika Medan. The data collection instruments used in this research and development were questionnaire sheets, interview sheets, and tests. The data analysis technique used is descriptive analysis technique. The descriptive analysis technique was carried out using descriptive statistics. All collected data were analyzed using descriptive statistical techniques which are quantitatively separated according to categories to sharpen the judgment in drawing conclusions. Qualitative data in the form of very poor, good, adequate, moderate, and very good statements are converted into quantitative data on a scale of 1 to 5 . Descriptively the percentage of values is formulated as follows:

Percentage Score $=\quad$ Total Score Received $\quad x 100$

the ideal number of scores for all items

(Arikunto, 2013: 272-273)

Calculation of research data using the formula above, will produce a number in the form of a percent $(\%)$. The score classification is then changed to a classification in the form of a percentage (Sugiyono, 2012: 137), then interpreted with a qualitative sentence. To determine the feasibility category of this learning media, a Likert scale measurement is used.

\section{Discussion}

\subsection{Results of the Development of Exposition Text Learning Media based on Genius Learning}

The results of the development of learning media for exposition text based on Genius Learning, namely in the form of a CD. The instructional media CD outlined contains a learning video about the exposition text material presented with audio visual media. The development of audio-visual learning media based on Genius Learning includes several components, such as text, images, animation, audio, and video.

The development of this learning media uses the Borg \& Gall model. This development activity begins with preliminary research (analyzing student needs), making learning media designs then developing the learning media using the Adobe After Effects application.

The next stage is product development which includes media component products such as text, images, animation, audio, and video. The initial product of this learning media was tried out to evaluate and obtain complete data that was used as material for product revision. Aspects that become materials for revising the product include components of content feasibility, material presentation, language and media appearance. 


\subsection{Feasibility of Learning Media}

The development research that has been carried out is directed to produce a product in the form of audio-visual learning media based on Genius Learning in exposition text learning for class $\mathrm{X}$ students of SMK Tritech Informatika. This research was conducted in order to improve the learning process and the competence of students. Therefore, in this research process is carried out by first conducting preliminary research, then designing the product, validating the product, revising the product, conducting product analysis, individual testing, small group testing, and field testing. This research process is carried out to produce learning media that is suitable for use in accordance with the characteristics of the field of study and students as users.

The results of the validation of the audio visual learning media product based on Genius Learning on the text material of the exposition can be detailed as follows.

(1) The results of the feasibility of validating learning media by material experts are declared "good". The results of the validation include 3 aspects of assessment, namely the feasibility of content, presentation of material, and language. The results of the assessment of these four aspects were declared "good" with an average percentage of $79 \%$.

(2) The results of the feasibility of validation of learning media by media experts are declared "good". The validation results include 2 aspects of assessment, namely content feasibility and graphic feasibility. The results of the assessment of these two aspects were declared "good" with an average percentage of $80 \%$.

(3) The results of the feasibility of validation of instructional media designs by instructional media design experts are stated to be "good" which includes aspects of attractiveness, appearance, and images / animation. The results of the validation of the three aspects were declared "good" with an average percentage of $82 \%$.

(4) The results of the student trial assessment were carried out in 3 processes, namely individual trials, small group trials, and field trials. The results of individual trials were declared "good" with an average percentage of $78.5 \%$. The results of the small group trial were declared "good" with an average percentage of $79 \%$. The results of field trials were declared "very good" with an average percentage of $83.54 \%$.

(5) The results of the assessment of 2 Indonesian language teachers on audio-visual learning media based on genius learning on exposition text material were stated to be "very good" with an average percentage of $86 \%$.

The conclusion from the research results that have been described above, namely the findings of the development of learning media are declared very feasible because material validation experts, media experts, and instructional media design experts are in the "good" category. The test results on students and teachers are also in the "very good" category.

\subsection{Effectiveness Leaming Media}

The effectiveness of learning media is seen from student learning. The results of learning to understand the exposition text of the tenth grade students of SMK Tritech Informatika using audio-visual learning media based on genius learning on the exposition text material are in the "good" category. The learning outcomes can be seen from the average value obtained by students after using the developed learning media. There are differences in the average score of students before and after using the developed learning media. The average score of students before using the developed learning media was $66.2 \%$, while the average score of students after using the developed learning media was $78 \%$. 
Seeing the increase in student learning outcomes described above, it can be concluded that the learning media developed is suitable for use in learning to improve student learning outcomes. As Kemp and Dayton (in Rusman, 2013: 168) state that the use of instructional media has contributed to the development and improvement of learning, namely as follows: (1) delivery of more standardized learning messages, (2) learning can be more interesting, (3) learning so it is more interactive by applying learning theory, (4) the implementation time of learning can be efficient, (5) the quality of learning can be improved; (6) learning can take place whenever and wherever needed, (7) increasing students' positive attitudes towards the learning material and process,

There are several theories on the use of instructional media, one of which is Dale's Cone of Experience theory (Dale, 1969). Dale estimates that learning outcomes obtained through the visual sense are around $75 \%$, the sense of hearing is around $13 \%$, and the other senses are around 12\% (Rusman, 2013: 165). This is what causes the use of learning media to be very important to use in learning activities.

From the description of learning outcomes and the theoretical views of the experts above, it can be concluded that the learning media is categorized as effective and suitable for use if students can understand the subject matter and student learning outcomes increase. Based on the research that has been done, the use of audio-visual learning media based on genius learning in exposition text material can increase interest in learning and student learning outcomes, especially in understanding the exposition text.

\section{Conclusion}

Based on the results of research on the development of audio-visual learning media based on genius learning on exposition text material for class $\mathrm{X}$ students of SMK Tritech Informatika, it can be concluded as follows.

1. The result of developing audio-visual learning media based on genius learning on exposition text material for this research is learning CD.

2. The learning media developed has conducted due diligence by experts, both material experts and design experts. The results of validation by material experts were declared "good" with all aspects of the assessment getting an average of $79 \%$, the results of validation by media experts were declared "good" with all aspects of the assessment getting an average of $80 \%$, validation by design experts was declared "very good" with All aspects of the assessment received an average of $82 \%$ and the response of Indonesian language teachers was an average of $86 \%$ on the "very good" criteria. The results of individual trials were declared "good" with an average percentage of $78.5 \%$. The results of the small group trial were declared "good" with an average percentage of $79 \%$. The results of field trials were stated "very good with an average percentage of $83.45 \%$.

3. Student learning outcomes in understanding exposition text after using audio-visual learning media based on genius learning are in the "good" category with an average value of 78 and an average value before using audio visual learning media based on genius learning on exposition text material of 66.2 . This proves that student learning outcomes are higher after using audio-visual learning media based on genius learning on exposition text material with a difference of 11.8 . 


\section{References}

Arikunto, S. (2013). Prosedur Penelitian: Suatu Pendekatan Praktik. Jakarta: Rineka Cipta.

Arsyad, A. (2011). Media Pembelajaran, Jakarta: Raja Grafindo Persada.

Arsyad, A. (2015). Media Pembelajaran Edisi Revisi. Jakarta: PT Raja Grafindo Persada

Bahri, Aliem. (2016). Kemampuan Menulis Teks Eksposisi Dengan Menggunakan Metode Cush Word. Konfiks: Jurnal Bahasa dan Sastra Indonesia, 3 (2): 93-102.

Dale. E. (1969). Audio Visual Methods in Teaching. New York: Holt, Rinehart and Winston Inc.

Dirdjosoemarto, S. (2000). Media Pembelajaran, Jakarta: Depdikbud.

Djamarah. (2006). Strategi Belajar Mengajar. Jakarta: Rhineka Cipta.

Juliani, R. \& Rahmat S. (2014). Penerapan Strategi Genius Learning untuk Meningkatkan Kualitas Hasil Belajar Mata Kuliah Rangkaian Listrik. Inovasi Pembelajaran Fisika, 1 (1): 61-69.

Kemendikbud. (2013). Pembelajaran Teks dalam Kurikulum 2013. Jakarta: Kemendikbud.

Kosasih, E. (2012). Dasar-dasar Keterampilan Menulis. Bandung: Yrama Widya.

Mahsun. (2013). Pembelajaran Berbasis Teks. Jakarta: Rineka Cipta.

Muttaqien, F. (2017). Penggunaan Media Audio Visual dan Aktifitas Belajar dalam Meningkatkan Hasil Belajar Vocabulary Siswa Pada Mata Pelajaran Bahasa Inggris Kelas X. Jurnal Wawasan Ilmiah, 8 (1).

Prasasti, T.I., Solin, M., and Hadi, W. (2019). The Effectiveness of Learning Media Folklore Text of North Sumatera Based on Blended Learning by 10th Grade Students of Vocational High SchoolHarapan Mekar-1 Medan. Budapest International Research and Critics in Linguistics and Education (BirLE) Journal Vol 2 (4): 480490.

Rusman. (2013). Model-model Pembelajaran. Jakarta: PT. Rajagrafindo.

Sanjaya, W. (2006): Strategi Pembelajaran Berorientasi Standar Proses Pendidikan Jakarta: Kencana Prenada Media Group.

Sitorus, L.S., Mardianto, and Matsum, H. (2020). Development of Powerpoint-Based Learning Media on Learning Aqeedah Morals. Budapest International Research and Critics in Linguistics and Education (BirLE) Journal Vol 3 (2): 958-964.

Sugiyono. 2012. Memahami Penelitian Kualitatif. Bandung: Alfabeta

Tegeh, I.M. et al. (2014). Model Penelitian Pengembangan. Yogyakarta: Graha Ilmu. 